İş ve İnsan Dergisi | The Journal of Human and Work

Y1l | Year: Ekim | October 2019

Cilt-Say1 | Volume-Issue: 6 (2)

ss I pp: $177-188$

doi: 10.18394/ iid.517569

e-ISSN 2148-967X

http://dergipark.gov.tr/iid/

Araştırma Makalesi

\title{
Örgütlerde Algılanan Mağduriyetin İntikam Niyetine Etkisinde İşyeri Arkadaşlı̆ğın Düzenleyici Rolü: Kayseri'de Bir İşletme Uygulaması
}

\author{
The Moderating Role of Workplace Friendship on the Effects of Perceived \\ Victimization on Revenge Intention: A Business Application in Kayseri
}

\section{Korhan Karacaoğlua ${ }^{a}$ M. Suat Aksoy ${ }^{b}$, Serhan Şahin ${ }^{c}$}

\section{MAKALE BİLGİSİ}

Anahtar Kelimeler:

Algilanan Mağduriyet,

Intikam Niyeti, İsyeri

Arkadaşlığı, Düzenleyicilik

Rolü

Tarihler:

Geliş 25 Ocak 2019

Düzeltme geliş 09 Mart

2019

Kabul 19 Mart 2019

\section{ARTICLE INFO}

\section{Keywords:}

Perceived Victimization,

Revenge Intention,

Workplace Friendship.

Moderating Role

Article history:

Received 25 January 2019

Received in revised form 09

March 2019

Accepted 19 March 2019

\section{ÖZ}

Bu çalışmanın amacl, Kayseri ilinde faaliyet gösteren bir imalat sanayi işletmesindek işgörenlerin mağduriyet algllamalarının, onların intikam niyetlerine nasıl etki ettiğinin belirlenmesi ve bu etkide ișyerindeki arkadaşllk iliş̧kilerinin düzenleyici bir role sahip olup olmadı̆̆ının ortaya konulmasıdır. Araștırmanın verileri, saha araștırması kapsamında, anket tekniği ile toplanan, 351 kişinin görüşlerinden ibarettir. Toplanan veriler uygun istatistiksel paket programlar kullanılarak regresyon analizi yoluyla test edilmiştir. Araştırmanın sonuçlarına göre, çallşanların doğrudan ve dolaylı mağduriyet algılamalarının, intikam niyetleri üzerinde anlaml bir etkiye sahip olduğu ve bu etkide işyeri arkadaşlı̆̆ının düzenleyici bir rol oynadı̆̆ bulgusuna ulaşılmıştır.

a İletişim kurulacak yazar, Doç. Dr.,, Nevşehir Hacı Bektaş Veli Üniversitesi, İktisadi İdari Bilimler Fakültesi, İşletme Bölümü, Nevşehir, Türkiye.E-mail: kkaracaoglu@nevsehir.edu.tr.ORCID:0000-0003-0577-231X b Dr. Ögrr. Üyesi, Erciyes Üniversitesi, İktisadi İdari Bilimler Fakültesi, İşletme Bölümü, Kayseri, Türkiye. E-mail:
maksoy@erciyes.edu.tr. ORCID: 0000-0002-6772-6768

c HASROPE Dıș Ticaret Uzmanı, Kayseri, Türkiye.E-mail: serhan5245@hotmail.com. ORCID: 0000-0003-2378-7742 


\section{GİRIŞ}

Rekabetin yoğunlaştığı günümüzde; işletmelerin ayakta kalması ve rekabet üstünlüğü sağlaması için insan kaynağının birbiriyle uyum içinde olması, örgütte yaşadığı sorunlar varsa, bunların giderilmesi önem arz etmektedir. $\mathrm{Bu}$ sorunların başında özellikle son yıllarda çalışanların mağduriyet algılamaları yer almaktadır.

Mağduriyet algılaması, alan yazında çok fazla işlenmemesine rağmen özellikle işletmelerde çalışanların sık karşılaştığı bir durum haline gelmiştir. Mağduriyet, sonuçları açısından; çalışanları olumsuz etkileyen, ruh sağlıkları üzerinde olumsuz etkiler birakan bir durumdur. Özellikle bu duruma sebebiyet veren saldırgan davranışların dikkatli şekilde incelenmesi ve çözümler bulunması çalışma hayatı ve barışı açısından büyük önem arz etmektedir. Öyle ki saldırgan davranışlara maruz kalan çalışanların verecekleri tepkiler gerek bireysel açıdan, gerekse işletme açısından ciddi tehlikeler oluşturabilecek potansiyele sahiptir. Çalışanların mağduriyete ilişkin verdikleri tepkiler; intikam niyetinde olma, içine atma, çekilme, kin besleme, kızgınlık duyma ve affetme şeklinde olabilmektedir (Gül, 2010).

Alan yazında çalışanların mağduriyet algılamalarının onları intikam niyetine sevk ettiğini ileri süren sınırlı sayıda çalışmaya rastlanmıştır (Aquino \& Bradfield, 2000; Aquino \& Thau, 2009; Çoklar, 2014; Yılmaz, 2014). Mağduriyetle baş etmenin çeşitli zorluklar içermesi sürece yönelik bir gerçeklik iken mağdurun faile yönelik düşünceleri, duyguları ve eylemleri, de süreçte önemli bir başka boyuttur. Bu noktada, intikam alma ve intikam alma isteği Stuckless (1996) tarafindan da belirtildiği gibi yaygın, fakat kaçınılmaz bir tepkidir (Gerlsma \& Lugtmeyer, 2018: 17). Teorik olarak Aquino ve Bradfield (2000) de mağduriyetin intikam niyetini teşvik ettiğini belirtirken, Aquino ve Thau (2009: 718) da sosyal destek arayışı ile birlikte intikam niyetini örgütlerde mağduriyetin sonuçları arasında saymaktadır. Türkçe alan yazında Yılmaz (2014) ve Çoklar (2014) tarafından her ikisi de hizmet sektöründe yapılan çalışmalarda mağduriyet algısındaki artışın intikam niyetini artırdığg sonucuna ulaşılmıştır.

İlgili alan yazındaki yukarıda vurgulanan kavramlar arasındaki ilişkilerden hareketle özellikle Türkiye'de özel sektör kuruluşlarında çalışanlar arasındaki rekabetin şiddeti ve çalışma ortamındaki çeşitli teşvik edici nedenlerden dolayı mağduriyetlerin yaşanabileceği bunun da zaman içinde intikam alma niyetini tetikleyebileceği düşüncesinden yola çıkılarak çalışma kurgulanmıştır. Konunun Türkiye'de daha önce hizmet sektöründe incelenmiş ancak imalat sanayinde incelenmemiş olması ve kavramlar arası ilişkide işyeri arkadaşlığının rolünün de ele alınmamış olması bakımından bu çalışmanın önemli olduğu ve ilgili alan yazına derinlik ve zenginlik kazandırma yönünde katk1 sağlayabileceği düşünülmektedir. Zira bu çalışmada varsayım olarak, iş yerindeki arkadaşlık ilişkilerinin iyi olmasının, çalışanların intikam almaya niyetlenmelerini azaltıcı, arkadaşlık ilişkilerinin zayıf veya kötü olmasının, intikam alma niyetlerini artırıcı yönde etkide bulunabileceği öngörüsünden hareket edilerek düzenleyici değişkene ilişkin kurgu yapılmıştır. Buradan yola çıkılarak çalışmada benimsenen temel amaç; örgütlerde mağduriyet algılamasının intikam niyeti üzerindeki etkilerinin ölçülmesi ve bu etkide işyeri arkadaşlığının düzenleyici rolü olup olmadığının ortaya konulmasıdır. Çalışma; kavramsal çerçeve ve saha araştırması sonucu elde edilen sonuçların değerlendirildiği toplam iki bölüm ve tartışma/sonuç kısımlarından oluşmaktadır.

\section{KAVRAMSAL ÇERÇEVE}

$\mathrm{Bu}$ başlık altında örgütlerden mağduriyet algısı, intikam niyeti ve işyeri arkadaşlığı kavramları arasındaki ilişkiye yer verilmiştir.

\section{1. Örgütlerde Mağduriyet Algısı ve İntikam Niyeti}

Örgütlerde saldırgan davranışlar son yıllarda önemli bir araştırma alanı haline gelmiştir. Bu alandaki çalışmalar ikiye ayrılabilir. Birinci grup çalışmalar, saldırgan davranışları kimlerin yaptığı ile ilgiliyken, ikinci grup çalışmalar ise saldırgan davranışlara kimlerin maruz kaldığı ile ilgilidir. Örgütlerde mağduriyet algılaması alanındaki çalışmalar bu iki gruptan ikincisine girmektedir. Yani örgütte saldırgan davranışlara maruz kalma ile ilgilidir (Özdevecioğlu \& Çelik, 2009: 97). Örgütlerde mağduriyete sebep olan saldırgan davranışlar arasında; hırsızlık, mobbing (psikolojik şiddet), tehdit, fiziksel şiddet, cinsel taciz gibi davranışlar bulunmaktadır.

Örgütlerde şiddet ve kötü davranışlar üzerine olan ilgi, çalışanların olumsuz davranışları üzerine gelişen bir çalışma alanı üretmiştir (Aquino, Grover, Bradfield \& Allen, 1999: 260). Mağduriyet algısı, bireyde bir ya da daha fazla kişinin anlık veya defalarca saldırgan davranışına maruz kalması sonucu oluşan algıdır (Aquino, 2000: 172). Diğer bir tanıma göre mağduriyet, haksızlığa uğrama durumu ve mazlumluk olarak tanımlanırken, bu 
durum bireysel ve toplumsal düzeyde yaşanabilir (Çevik, 2013: 65). Örgütlerde algılanan mağduriyet ise bir çalışanın aynı örgütte bulunan ve hâlihazırda iletişim içinde olduğu başka bir çalışan tarafından geçici ve sürekli hedef olarak seçilmesi ve duygusal, psikolojik veya fiziksel olarak bundan zarar gördüğünü algılamasıdır (Aquino \& Lamertz, 2004: 1023).

Örgütlerde mağduriyet, çalışanların örgütte karşı karşıya kaldıkları veya kaldıklarını hissettikleri mağduriyet halini ifade etmektedir (Özdevecioğlu \& Çelik, 2009: 96). Başka bir ifadeyle mağduriyet, bir çalışanın, bir kişi veya grup tarafından kendisine yöneltilen sürekli ve tekrarlı saldırgan davranışlara maruz kalmasına dair algılamasıdır (O'Leary-Kelly, Griffin \& Glew, 1996: 226). Dolayısıyla mağduriyetin hem gerçek hem de algılanan yanından bahsedilebilir.

Algilanan mağduriyete sebep olan saldırgan davranışlar bireyi doğrudan hedef almıyorsa bu dolaylı mağduriyet olarak adlandırılmaktadır. Bunun yanı sıra eğer saldırgan davranış bireyi direkt olarak hedef aliyorsa bu durum doğrudan mağduriyet olarak adlandırılmaktadır (Aquino, 2000: 180). Dolaylı mağduriyet daha ziyade bireyin çalışmasını engellemeye yönelik saldırgan davranışlara maruz kalmayı ifade etmektedir.

Alan yazında mağduriyet konusuna kuramsal açıdan temel teşkil eden iki teori bulunmaktadır. Bunlar; yaşam tarzı teorisi ve rutin aktivite teorisidir (Hindelang, Gottfredson \& Garofalo, 1978; Cohen \& Felson, 1979). Hindelang ve diğerleri (1978) tarafından geliştirilen yaşam tarzı teorisine belirli sosyal karakteristik özelliklere sahip kişilerin diğer sıradan kişilere göre daha fazla mağduriyet riski taşıdığı varsayılmaktadır. Bir başka deyişle kişinin mağduriyeti rastgele bir sebepten dolayı değil, kendisini mağdur durumuna düşürecek bir yaşam tarzı seçip onu yaşadığ 1 içindir. Diğer bir teori ise Cohen ve Felson (1979) tarafından ortaya atılmış rutin aktivite teorisidir. Bu teori kriminal alanda üzerinde en çok durulan ve kriminal mağduriyeti açıklamak için yaygın bir şekilde kullanılan bir yaklaşımdır.

Çalışan kişinin mağdur olduğunu algılamasının bireysel ve örgütsel açıdan olumsuz sonuçları vardır. Kendisini mağdur olarak algılayan bireylerin fiziksel olarak sağlıklarının bozulması, panik atak ve hatta yaşamlarının tehdit altında olduğunu düşündükleri olmuştur (Gül, 2010). Aynı şekilde bu kişiler başka insanların gözünde değerlerinin düştüğünü, örgüt içindeki statülerini, kontrol yetilerini kaybedebileceklerini düşünmekte ve özsaygılarını yitirmektedirler (Taylor, Wood \& Lichtman, 1983: 23). Doğrudan şiddetle ve saldırgan davranışla yüzleşip mağdur olan insanlarda gelecek zamanda yine şiddete maruz kalacağına dair korkular oluşmakta, duygusal iyilikte ve psikomatik iyilikte azalma, örgüte karşı bağlılıkta azalma ve gerek örgüte gerekse örgütteki bireylere karşı olumsuz davranışlar sergileme eğiliminde artış görülmektedir (LeBlanc \& Kelloway, 2002: 445). Fiziksel olarak zarar görmenin yanı sıra, mağdurlarda stres ve endișe görülmektedir. Bunun sonucu ise göz ard1 edilmemesi gereken tükenmişlik ve uzun dönemli psikolojik rahatsızlıklar olarak ortaya çıkmaktadır. Depresyon da bunlardan biridir. Bununla birlikte kişinin kendine duyduğu; özsaygının azalması, stres ve fiziksel rahatsızlıklar söz konusu olmaktadır (Kaukiainen vd., 2001: 362). Mağduriyet algısının sebep olduğu sorunlardan birisi de iş tatmininde azalmadır (Lapierre, Spector \& Leck, 2005: 158).

Mağduriyet algılayan kişiler; korku, stres, travma sonrası stres bozuklukları gibi olumsuz durumlar yaşamakta ve bu saldırgan davranışlara karşılık verme durumunda kalmaktadırlar. $\mathrm{Bu}$ karşılık verme durumlarından birisi de intikamdır (Frederic vd., 2013: 16). Örgütsel davranış yazınında intikam, genellikle eşitsizlik ve adaletsiz uygulamalar sonucu mağdur hale gelen kişilerin başvurduğu bir davranıs olarak ele alınmaktadır (Tatarlar \& Çangarlı, 2018: 592). İntikam alma ve intikam alma niyeti (yani, bir kişiye ya da kendisine ya da ailesinin kasıtlı zararı olanlara karşı saldırgan bir tepki verme) Stuckless, (1996) tarafindan yaygın, fakat kaçınılmaz bir karşı koyuş olarak değerlendirilmektedir (Gerlsma \& Lugtmeyer, 2018: 17). Bies ve Tripp (1996) kendisine yanlış yapıldığını düşünen kişinin, ona bu yanlışı yapanla ödeşme isteği içinde olacağını, dolayısıyla normalde intikam gibi etik dişı değerlendirebileceği birtakım davranışları gösterebileceğini belirtmişlerdir. Bireyin yaşadığg her mağduriyet onu intikam alma niyetine sevk eder mi bunun cevabı mağdurun intikam alma firsatına sahip olup olmamasına, suçlu ve kurban arasındaki ilişkilerin yakınlığına, kurbanın ve suçlunun gücüne, örgüt kuralları ve tarafların kişilik özelliklerine göre değişir. Ayrıca mağdurun faile karşı sahip olduğu gücü ve intikam alma firsatlarının fazla oluşu da intikam niyetini kuvvetlendirir (Bies, Aquino \& Tripp, 2007: 14). Mağdur eğer ast pozisyonunda ise failden intikam alması güç hale gelir. Ancak tersi durumda fail ast pozisyonunda ise mağdur üst pozisyonunda olduğundan bu durumda mağdur mevki gücünden dolayı intikam almaktan korkmaz (Akın, Özdevecioğlu \& Ünlü, 2012). Mağdurun intikam niyetine yönelip yönelmemesine sebep olan bir başka faktör de mağduriyete yol açan olayın ciddiyetidir. Olay ne kadar ciddi ve sebep olduğu zarar ne kadar büyük ise intikam niyeti de o kadar güçlü olacaktır (Bies vd., 2007: 17). 
Alan yazında intikam alma biçimleri arasında, örgütsel vatandaşlık davranışlarının azalması, geri çekilme ve direnç oluşturma gibi dolaylı (Jermier, Knights \& Nord, 1994) ya da kötü davranış sergileyen kişiyi örgüt içerisinde aşağılama, görünür biçimde özür bekleme, kötü söz söyleme, ispiyonlama ve dava etme şeklinde doğrudan (Bies \& Tripp, 1996) olabileceği belirtilmiştir.

Teorik olarak Aquino ve Bradfield (2000) örgütlerde mağduriyetin intikam alma niyetini teşvik ettiğini ileri sürmüştür. Ayrıca Aquino ve Thau (2009: 718) sosyal destek arayışı ile birlikte intikam niyetini örgütlerde mağduriyetin sonuçları arasında saymaktadır. Yilmaz (2014) tarafindan Türkiye'de konaklama işletmeleri üzerinde yapılan araştırmada mağduriyet algısındaki artışın intikam niyetini artırdığı sonucuna ulaşılmıştır. Çoklar (2014) da akademik personel üzerinde gerçekleştirdiği araştırmada, mağdur durumunda ya da kendisini mağdur olarak algılayan bireyin intikam niyetinin arttığını tespit etmiştir.

Alan yazındaki bu ilişkilerden hareketle çalışma için geliştirilen ilk iki hipotez aşağıdaki gibidir:

H1: Çalışanların doğrudan mağduriyet algıları, intikam niyetlerini olumlu ve anlamlı yönde etkilemektedir.

H2: Çalışanların dolaylı mağduriyet algıları, intikam niyetlerini olumlu ve anlamlı yönde etkilemektedir.

\section{2. Örgütlerde Mağduriyet Algısının İntikam Niyetine Etkisinde İşyeri Arkadaşlığının Düzenleyici Rolü}

İşletmelerde verimliliği etkileyen çeşitli unsurlar vardır. $\mathrm{Bu}$ unsurların en önemlilerinden birisi olan işyeri ortamı, çalışanların moral ve motivasyonu açısından, örgüte bağlılık hissetmeleri, kendilerine bir sosyal çevre oluşturmaları açısından oldukça önemlidir. Sosyal çevrede ise en önemli etken, çalışanın aynı işletme içinde kurduğu sosyal bir bağ olan işyeri arkadaşlığıdır.

İşyerindeki arkadaşlık ilişkileri; insanlarda sosyal bir destek algısı oluştururken, kendilerine, çalışma arkadaşlarına ve nihayetinde çalıştıkları örgütlere karşı güven duygularını geliştirmektedir. Araştırmacılar, işyerindeki yakın arkadaşlıkları, iş görenlerin hayatlarında mutluluk ve motivasyon kaynağ1 olarak gördüklerini ifade etmektedir (Alparslan, Çiçek \& Soydemir, 2015: 176). İşyeri arkadaşlığı çalışanlara maddi ve manevi destek sağlayan ve geleneksel kaynaklara alternatif oluşturan önemli bir unsurdur. İşyeri arkadaşlığı, çalışan için gerçekten büyük bir ödüldür ve aynı zamanda iş kaynaklı stresi nerdeyse engelleyen, iş tatminsizliğini ve çalışan devir hızını azaltan bir faktördür (Kram \& Isabella, 1985: 117).

Arkadaşlık ilişkilerinin nedenlerini ve bu arkadaşlık ilișkilerinin hangi etmenlerle var olduğunu ve sürdürülebildiği açıklayan kuramlar vardır. Festinger (1954)'in sosyal karşılaştırma kuramına göre, insanlar kendi duygu ve düşünceleri ile aynı duygu ve düşüncelere sahip olan insanlarla bir araya geldiğinde kendini rahat hisseder. İnsanlar kendi tutum ve düşüncelerinin doğruluğunu teyit etmek için kendisine benzer kişilerle beraber olmak istemektedirler (Gemlik, Sı ğrı \& Sur, 2007: 55). Bir diğer kuram Byrne ve Clore (1970) tarafindan koşullanma kuramı olarak ifade edilmiştir. $\mathrm{Bu}$ kuram kişilerin kendi değer ve inançlarını paylaşan kişilerden etkileneceğini söyler. Kişinin ilişki kuracağı kişi ile aynı fikri paylaştığında kendini onaylanmış hissedeceğini ve bu kişi ile tekrar ilişki kurmak isteyeceğini açıklar (Alparslan vd., 2015: 179). Devam eden ilişkileri açıklayan Sosyal Değişim Kuramı; ilişskinin tatmin edici olması için ödüllerin/karşılıklı değişimin olmasını, bunun da eşit bir şekilde gerçekleşmesi gerektiğini ileri sürer (Emerson, 1976: 335-362). Gelişim kuramı ise, arkadaşlıkların statik olmadığını, zamanla oluştuğu görüşünü savunarak işyeri arkadaşlık kavramına farklı bir bakış kazandırmıştır (Adams \& Blieszner, 1994: 163-184).

İşyeri arkadaşlı̆̆ı sayesinde çalışanlar, sapkın davranışlar sonucu doğabilecek mağduriyetler ve bunun sonucunda ortaya çıkabilecek intikam alma niyetinin de önüne geçebilme olanağına sahip olabileceklerdir. Örgütlerde ortaya çıkabilecek mağduriyet algıları intikam niyetini artırırken işyeri arkadaşlığının bu etkiyi azaltıcı yönde bir düzenleyici rol oynayacağı beklenmekte ya da aksine işyerindeki arkadaşlık ilişkileri kötü ise bu etkiyi artıracağı yönünde bir düzenleyicilik rolü üstleneceği öngörülmektedir. Buradan hareketle araştırmanın üçüncü ve dördüncü hipotezleri aşağıdaki gibidir.

H3: Çalışanların doğrudan mağduriyet algılarının, intikam niyetlerine olumlu yönde etkisinde işyeri arkadaşlığı düzenleyici etkiye sahiptir.

H4: Çalışanların dolaylı mağduriyet algılarının, intikam niyetlerine olumlu yönde etkisinde işyeri arkadaşlığı düzenleyici etkiye sahiptir. (Bkz. Şekil 1) 


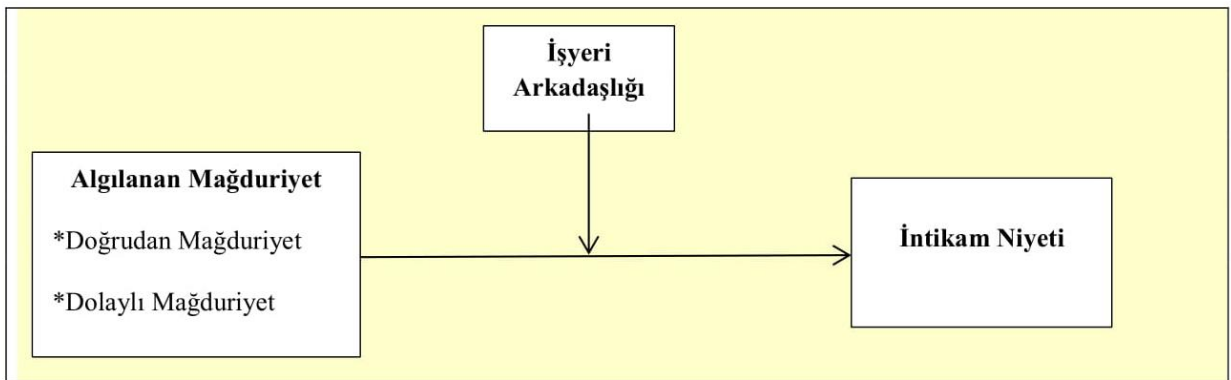

Şekil 1: Araştırmanın modeli

\section{ARASTIRMANIN YÖNTEMI}

Bu çalışmanın evreni, Kayseri ilindeki demir çelik sektöründe faaliyet gösteren bir işletmedeki 370 çalışandır. Bu çalışanlardan 355 kişiden anketlere yanıt alınmış ancak 351 kullanılabilir anket analizlere dâhil edilmiştir.

Araştırmada Aquino ve diğerleri (1999) tarafından geliştirilen ve sekiz maddeden oluşan algılanan mağduriyet ölçeği kullanılmıştır. Likert tipi ölçekteki ifadeler 1 "Hiçbir zaman"dan 5 "Her zaman"a doğru sıralanmıştır. Bu ölçekte ilk dört ifade doğrudan mağduriyeti, son 4 ifade de dolaylı mağduriyeti ölçmeyi amaçlamaktadır. Ölçeğin Türkçe geçerlemesi Ülbeği ve diğerleri (2014) tarafindan yapılmıştır. Bu çalışma için Cronbach alfa güvenilirlik katsayısı 0,85 olarak hesaplanmıştır.

İntikam niyetini ölçmek için Wade (1989) tarafindan geliştirilen ve toplam beş sorudan oluşan intikam ölçeği kullanılmıştır. Ölçeğin Cronbach alfa güvenilirlik katsayısı 0,84 'tür. Likert tipi ölçekteki ifadeler, 1 "Hiçbir zaman"dan 5 "Her zaman"a doğru sıralanmıştır.

İşyeri arkadaşlığı değişkenini ölçmek için Nielsen, Jex ve Adams (2000) tarafindan geliştirilen ve 12 maddeden oluşan ölçeğin bu çalışmanın amacına uygun olduğu düşüncesinden hareketle sadece arkadaşlık algıları ile ilgili olan 6 maddesi kullanılmıştır. 5'li Likert tipi bir ölçek olarak tasarlanan bu ölçekteki ifadeler (1) "Kesinlikle katılıyorum"dan (5) “Kesinlikle katılmiyorum"a doğru değerler almaktadır. Ölçeğin alfa güvenilirlik katsayısı 0,82'dir.

Çalışmada kullanılan ölçeklerin geçerliğini test etmek amaciyla LISREL paket programı kullanılarak doğrulayıcı faktör analizleri yapılmış ve ölçeklerin uyum iyiliği değerlerine ilişkin sonuçlar aşağıdaki Tablo 1'de özetlenmiştir.

"YEM araştırmalarında, $\chi 2 /$ sd'nin rapor edilmesi konusunda araştırmacılar arasında bir görüş birliği olsa da (Mulaik vd., 1989); diğer uyum indekslerinden hangilerinin rapor edilmesi gerektiğine ilişkin farklı görüşler bulunmaktadır. McDonald ve Ho (2002); CFI, GFI, NFI ve NNFI (TLI); Garver ve Mentzer (1999); RMSEA, CFI ve NNFI (TLI); Brown (2006); RMSEA, SRMR, CFI ve NNFI (TLI); Iacobucci (2010), CFI ve SRMR uyum indekslerinin rapor edilmesini önermektedirler. Gerbing ve Anderson (1992) ise araştırmacının amacına bağll olarak farklı uyum indekslerinin raporlanabileceğini ifade etmektedir" (Aktaran, Ilhan \& Çetin, 2014: 31).

Yukarıdaki alan yazın bilgisinden hareketle bu araştırmada çalışmalarda sıklıkla başvurulan; $\mathrm{X}^{2} / \mathrm{df}$, GFI, AGFI, RMSEA, NFI ve CFI uyum iyiliği istatistikleri Tablo 1'deki gibidir.

Elde edilen sonuçlara göre araştırmada kullanılan ölçeklerin uyum iyiliği değerleri SchermellehEngel, Moosbrugger ve Müller'in (2003) belirttiği gibi iyi uyum düzeyini yansıtmaktadır. Buna göre kullanılan ölçeklerin geçerliği bu çalışmanın verileri ile de doğrulanmaktadır.

Araştırmada, değişkenler arasındaki ilişsilere dair

Tablo 1: Araştırmada Kullanılan Ölçeklerin Doğrulayıcı Faktör Analizi Sonuçları ve Uyum İyiliği İ̀statistikleri

\begin{tabular}{llllllll}
\hline Model & $\mathbf{X}^{\mathbf{2} / \mathbf{d f}}$ & $\mathbf{R M S E A}$ & GFI & CFI & AGFI & NFI & SRMR \\
\hline Doğrudan Mağduriyet Boyutu & 2,46 & 0,060 & 0,95 & 0,91 &, 93 &, 92 &, 06 \\
\hline Dolaylı Mağduriyet Boyutu & 2,24 & 0,055 & 0,94 & 0,94 &, 92 &, 93 &, 04 \\
\hline İntikam Niyeti Ölçeği & 1,47 & 0,067 & 0,92 & 0,91 &, 91 &, 92 &, 06 \\
\hline İșyeri Arkadaşlığı Ölçeği & 2,92 & 0,056 & 0,93 & 0,91 &, 89 &, 91 &, 07 \\
\hline İyi / Kabul Edilebilir Uyum & $\mathbf{\leq 3}$ & $\mathbf{\leq . 0 8}$ & $\mathbf{2 . 9 0}$ & $\mathbf{2 . 9 0}$ & $\mathbf{\geq . 8 5}$ & $\mathbf{2 . 9 0}$ & $\leq . \mathbf{. 1 0}$ \\
\hline
\end{tabular}


bulgular ve analiz sonuçlarına aşağıda yer verilmiştir. Araştırmalarda, verilerin normal dağılım gösterip göstermemesi, kullanılacak analiz yöntemlerinin belirlenmesinde büyük önem taşımaktadır. Dağılımın normal olup olmadığından söz edilebilmesi için, alan-yazında önerilen yöntemlerden olan çarpıklık ve basıklık değerleri ile veriler test edilmiştir (Çokluk, Şekercioğlu \& Büyüköztürk, 2012; Gürbüz \& Şahin, 2014). Normal olarak dağılım gösteren bir verinin çarpıklık ve basıklık değerlerinin -3 ve +3 aralığında olması gerekmektedir (Tabachnick \& Fidell, 2012). İlgili alan-yazından hareketle bu araştırmada yer alan ifadelerin çarpıklık ve basıklık değerlerinin -3 ve +3 değerleri arasında olması ve verilerin normal dağılım göstermesi analizlerde parametrik testlerin tercih edilmesine sebep teşkil etmiştir.

\section{BULGULAR}

Araştırmada yer alan değişkenlere ait Korelasyon katsayıları Tablo 2'de yer almaktadır.

Tablo 2'ye bakıldığında doğrudan mağduriyetin kullanımında "bias-corrected§" önyükleme güven aralıkları incelendiği için önerildiği üzere Z-Score hesaplamaları yapılmıştır.

Tablo 3'deki hiyerarşik regresyon analizi sonuçlarına göre doğrudan mağduriyetin intikam niyetini yordama gücünün anlamlı olduğu görülmektedir. $[F=5,3930, p<0,0427]$. Analiz sonuçlarına göre $\mathrm{R}^{2}$ değeri 0,0445 'dir. $\mathrm{Bu}$ sonuçla intikam niyeti değişkenindeki varyansın 0,0445 gibi küçük bir kısmının doğrudan mağduriyet değişkenine bağlı olduğu bulgusuna ulaşılmıştır. Buna göre araştırmanın $\mathrm{H}_{1}$ hipotezi desteklenmektedir.

Tablo 3'deki analiz sonuçlarına göre int_1 (Doğrudan Mağduriyet*İşyeri Arkadaşlığı) etkileşim teriminin anlamlı olması $(p=0,0050)$ düzenleyici değişkenin varlığına işaret etmektedir. Bunun yanında güven aralığının alt sınırı olan LLCI $(-, 2570)$ değeri ile güven aralığının üst sınırı olan ULCI (-,0461) değerinin sıfirı kapsamaması etkileşim teriminin anlamlı olduğuna ilişskin bir diğer kanıttır. Yine Tablo 3'de sirasıyla, bağımsız değişken, düzenleyici değişken ve etkileşim terimlerinin her bir model için etki düzeylerinin anlamlılığına ilişkin analiz sonuçları yer almaktadır.

Tablo 2: Değişkenlere İlişkin Korelasyonlar

\begin{tabular}{lllllll}
\hline Değişkenler & Ort. & Stn.Sap. & $\mathbf{1}$ & $\mathbf{2}$ & $\mathbf{3}$ & $\mathbf{4}$ \\
\hline 1. Doğrudan Mağduriyet & 1,47 & 0,61 & 1 & & & \\
\hline 2. Dolaylı Mağduriyet & 1,47 & 0,71 & $0,654^{* *}$ & 1 & & \\
\hline 3. İntikam Niyeti & 2,20 & 1,13 & $0,129^{*}$ & $0,218^{* *}$ & 1 & \\
\hline 4. İșyeri Arkadaşlı̆̆ & 4,28 & 0,85 & 0,035 & $0,167^{* *}$ & 0,082 & 1 \\
\hline
\end{tabular}

$\mathrm{n}: 351,{ }^{*} \mathrm{p}<.05,{ }^{* *} \mathrm{p}<.01,{ }^{* * *} \mathrm{p}<.001$

intikam niyeti üzerinde $(0,129)$ düzeyinde, dolaylı mağduriyetin ise $(0,218)$ düzeyinde pozitif yönlü ve zayıf bir ilişki ortaya koyduğu görülmektedir. Ayrıca Tablo 1'deki ortalama değerleri sütununa bakıldığında çalı̧̧anların doğrudan ve dolaylı mağduriyet algılamalarının ortalama 1,47 ile "nadiren" mağduriyet yaşadıkları ifadesine yakın bir düzeyde olduğu, intikam niyeti ortalaması 2,20 ile "nadiren" değerinin biraz üzerinde "ara sıra" ifadesine yakın bir seviyededir. İ̧̧yeri arkadaşlığı ile ilgili ifadelere verilen yanitların genel ortalaması 4,28 ile katılıyorum seçeneğine yakın bir değerdir.

Doğrudan mağduriyetin çalş̧anların intikam niyetlerine etkisinde işyeri arkadaşlığının düzenleyici rolünü belirleyebilmek için $\mathrm{A}$. Hayes (2013)'in geliştirdiği ve SPSS paket programı alt yapisı ile çalışan PROCESS macro (v3.2) kullanılmıştır. Etkileşimli etkinin incelenmesinde Hayes (2013: 112) tarafindan önerilen adımlar dikkate alınmıştır. $\mathrm{Bu}$ noktada PROCESS
Regresyon analizinde düzenleyici değişkenden söz edebilmek için bağımsız değişkenin bağımlı değişken üzerindeki etkisi anlamlı iken düzenleyici değişkenin bağımlı değișken üzerindeki etkisinin anlamsiz olması beklenmektedir (Aksu, Eser \& Güzeller, 2017: 217). Tablo 3'e bakıldığında bir önceki cümlede belirtildiği gibi düzenleyici değişken olan işyeri arkadaşlığının intikam niyeti üzerinde anlamlı bir etkisinin olmadığı görülmektedir. Ne zaman etkileşim terimi devreye girmekte o zaman işyeri arkadaşlığ 1 doğrudan mağduriyet ve intikam niyeti arasındaki ilişkiyi düzenleyici bir hüviyet kazanmaktadır.

Tablo 3'den hareketle farklı düzeylerdeki işyeri arkadaşlığının, doğrudan mağduriyet ve intikam niyeti arasındaki ilişkideki düzenleyici etkisinin incelenmesi sonucunda aşağıdaki bulgulara da ulaşılmıştır:

§ 5000 önyükleme yapılarak \%95 oranında yanlılığ1 düzeltilmiş güven aralığıdır. 
Tablo 3: Doğrudan Mağduriyetin Çalışanların İntikam Niyetleri Üzerindeki Etkisinde İşyeri Arkadaşlığının Düzenleyici Rolü

\begin{tabular}{lcccccc}
\hline Bağımsız Değişkenler & $\mathbf{B}$ & se & $\mathbf{t}$ & $\mathbf{p}$ & LLCI & ULCI \\
\hline$R^{2}=0,0445 F(3,347)=5,3930$ & $p<0,012 \Delta R^{2}=0,0220$ & $F(1,347)=7,99$ & $p=0,005$ & & \\
\hline Sabit & 2,2093 &, 0592 & 37,2905 &, 0000 & 2,0928 & 2,3258 \\
\hline Doğrudan Mağduriyet &, 1216 &, 0598 & 2,0337 & $\mathbf{0 4 2 7}$ &, 0040 &, 2392 \\
\hline İşyeri Arkadaşlığı &, 1063 &, 0597 & 1,7799 &, 0760 &,- 0112 &, 2237 \\
\hline int_1Doğ.Mağd.*ișsy.Arkadaş &,- 1515 &, 0536 & $-2,8276$ & $\mathbf{, 0 0 5 0}$ &,- 2570 &,- 0461 \\
\hline
\end{tabular}

Bağımlı Değişken: İntikam Niyeti

Farkı İşyeri Arkadaşı̆̆ı Düzeylerinde Doğr. Mağduriyetin İntikam Niyetine Etkisi

\begin{tabular}{lllllll}
\hline & B & se & t & p & LLCI & ULCI \\
\hline$-1,00$ SD &, 2731 &, 0751 & 3,6310 & $\mathbf{, 0 0 0 3}$ &, 1252 &, 4211 \\
\hline M (,00) &, 1216 &, 0598 & 2,0337 & $\mathbf{, 0 4 2 7}$ &, 0040 &, 2392 \\
\hline$+1,00$ SD &,- 0299 &, 0851 &,- 3520 &, 7250 &,- 1972 &, 1374 \\
\hline
\end{tabular}

Not: LLCI $=$ \% 95güven aralığının alt sınırı; ULCI $=$ \% 95güven aralığının üst sınırı

Yanlılık hatasından arındırılmış 5000 örneklem bootstrap metodu kullanıldı. Regresyon katsayıları standardize edilmedi.

a) İşyerindeki arkadaşlık ilişkileri zayıf veya kötü olduğunda (-1 SD), bu durumun mağduriyet yaşayanları intikam niyetine yönelttiği yani iş yerindeki arkadaşlık ilişkileri kötü ise mağduriyet ve intikam niyeti arasındaki ilişkinin anlamı ve pozitif yönlü bir biçimde ortaya çıktı̆̆ tespit edilmiştir $\quad(\mathrm{B}=, 2731, \quad \mathrm{se}=, 0751, \mathrm{t}=3,6310$ ve $\mathrm{p}=, 0003)$.

b) İşyerindeki arkadaşlık ilişkileri orta düzeyde ise, bu durumunda mağdur olanlarda intikam alma niyetini geliştirdiği yani mağduriyet algısının intikam niyetini anlamlı ve pozitif yönde etkilediği bulgusuna ulaşılmıştır $\quad(B=0,1216, \quad S E=0,0598$; $\mathrm{t}=2,0337, \mathrm{p}=0,0427$ ).

c) İşyerindeki arkadaşlık ilişkileri iyi veya düzey olarak yüksek ise (+1 SD), bu durum çalışanların mağduriyet yaşasalar da intikam niyetine yönelmediklerini başka bir deyişle mağduriyet algısı ile intikam niyeti arasındaki ilişkinin anlamsız hale geldiği görülmektedir.

$\mathrm{SE}=0,0851 ; \mathrm{t}=-, 3520 ; \mathrm{p}=, 7250)$.

$\mathrm{Bu}$ sonuçlardan hareketle Grafik 1'de görülebileceği gibi düzenleyici değişken olarak

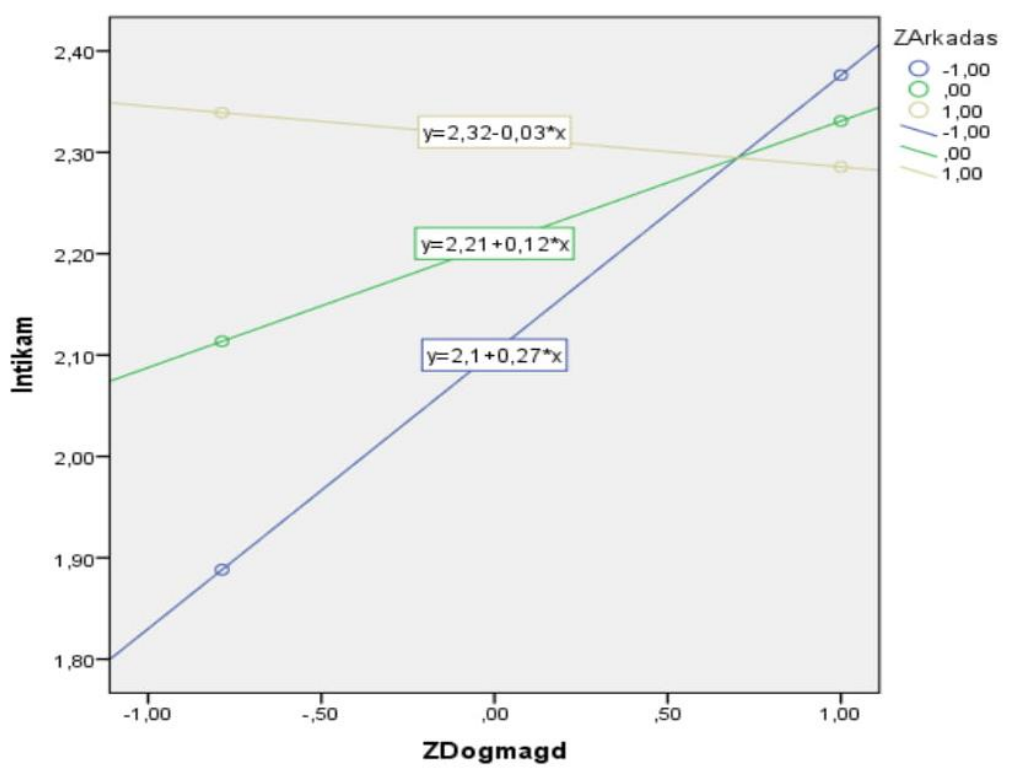

Grafik 1: Farklı İşyeri Arkadaşlığı Düzeylerinde Doğrudan Mağduriyet ve İntikam Niyeti İlişkisi 
tanımlanan işyeri arkadaşlığı eğiliminin ortalamanın bir standart sapma altı olarak (-1,00 SD) düşük ve ortalama civarında $(, 00)$ orta seviyede olduğunda doğrudan mağduriyet ve intikam niyeti ilişkisini düzenlemede anlamlı bir etkiye sahip olduğu, ortalamanın bir standart sapma üstü $(+1,00$ SD) yüksek şeklinde tanımlanan koşulda ise doğrudan mağduriyetin ve intikam niyeti ilişkisini düzenlemede anlamlı bir etkiye sahip olmadığı belirlenmiştir.

Elde edilen bu sonuçlara göre işyeri arkadaşlığının, doğrudan mağduriyet ve intikam niyeti arasında düzenleyici bir değişken etkisine sahip olduğu sonucuna varılmıştır. Bu sonuçlardan hareketle araştırma için geliştirilen $\mathrm{H}_{3}$ hipotezi desteklenmektedir.

Tablo 4'deki regresyon analizi sonuçlarına göre dolaylı mağduriyetin intikam niyetini yordama gücünün anlamlı olduğu görülmektedir. $[\mathrm{F}=7,3819$, $\mathrm{p}=0,000]$. Analiz sonuçlarına göre $\mathrm{R}^{2}$ değeri 0,06 'dır. Bu sonuçla intikam niyeti değişkenindeki varyansın \%6 gibi küçük bir kısmının doğrudan mağduriyet değişkenine bağlı olduğu bulgusuna ulaşılmıştır. Buna göre araştırmanın $\mathrm{H}_{2}$ hipotezi desteklenmektedir.

Tablo 4'e göre etkileşim teriminin (int_Dolaylı Mağduriyet*İşyeri Arkadaşlığı) modele eklenmesi ile kurulan regresyon modelinin istatistiksel olarak anlamlı olduğu $(\mathrm{p}=0,0497)$ görülmektedir. $\mathrm{Bu}$ bulgudan hareketle, dolaylı mağduriyetin intikam niyetine etkisinde, işyeri arkadaşlığının düzenleyici rolü olduğunu ileri süren $\mathrm{H}_{4}$ hipotezi desteklenmektedir.
Tablo 4'deki analiz sonuçlarına göre int_1 (Dolaylı Mağ*İşyeri Ark) etkileşim teriminin anlamlı olması $(p=0,0497)$ düzenleyici değişkenin varlığına işaret etmektedir. Bunun yanında güven aralığının alt sınırı olan LLCI $(-, 1967)$ değeri ile güven aralığının üst sınırı olan ULCI $(-, 0002)$ değerinin sıfırı kapsamaması etkileşim teriminin anlamlı olduğuna ilişskin bir diğer kanıttır.

Tablo 4'den hareketle farklı düzeylerdeki işyeri arkadaşlığının, dolaylı mağduriyet ve intikam niyeti arasındaki ilişkideki düzenleyici etkisinin incelenmesi sonucunda aşağıdaki bulgulara da ulaşılmıştır:

a) İşyerindeki arkadaşlık ilişkileri zayıf veya kötü olduğunda (-1 SD), bu durumun dolaylı mağduriyet yaşayanları intikam niyetine yönelttiği yani iş yerindeki arkadaşlık ilişkileri kötü ise mağduriyet ve intikam niyeti arasındaki ilişkinin anlamı ve pozitif yönlü bir biçimde ortaya çıktığ 1 tespit edilmiştir $(\mathrm{B}=, 3488, \quad \mathrm{se}=, 0823, \mathrm{t}=4,2385$ ve $\mathrm{p}=, 000)$.

b) İşyerindeki arkadaşlık ilişkileri orta düzeyde ise, bu durumunda dolaylı yönden mağdur olanlarda intikam alma niyetini geliştirdiği yani mağduriyet algısının intikam niyetini anlamlı ve pozitif yönde etkilediği bulgusuna ulaşılmıştır $\quad(B=0,2504$, $\mathrm{SE}=0,0600 ; \mathrm{t}=4,1706, \mathrm{p}=0,000)$.

c) İşyerindeki arkadaşlık ilişskileri iyi veya düzey olarak yüksek ise (+1 SD), bu durum da çalışanlar dolaylı mağduriyet yaşadıklarında intikam niyetine yönelmektedirler $\quad(B=0,1520 ; \quad S E=0,0737 ; \quad t=-$ $2,0625 ; \mathrm{p}=, 0399)$.

Tablo 4: Dolaylı Mağduriyetin Çalışanların İntikam Niyetleri Üzerindeki Etkisinde İşyeri Arkadaşlığının Düzenleyici Rolü

\begin{tabular}{|c|c|c|c|c|c|c|}
\hline Bağımsız Değişkenler & B & se & $\mathbf{t}$ & $\mathbf{p}$ & LLCI & ULCI \\
\hline \multicolumn{7}{|c|}{$R^{2}=0,06 F(3,347)=7,3819 p<0,01 \Delta R^{2}=0,0220 F(1,347)=3,8803 p=0,0497$} \\
\hline Sabit & 2,2204 & 0593 & 37,4292 & ,0000 & 2,1037 & 2,3371 \\
\hline Dolaylı Mağduriyet & ,2504 & ,0600 & 4,1706 & ,000 & ,1323 & ,3685 \\
\hline İşyeri Arkadaşlığı & ,0667 & ,0601 & 1,1100 & ,2678 &,- 0515 &, 1848 \\
\hline int_1Dolaylı.Mağd.*İşy.Arkadaş &,- 0984 &, 0500 & $-1,9699$ & ,0497 &,- 1967 &,- 0002 \\
\hline \multicolumn{7}{|l|}{ Bağımlı Değişken: İntikam Niyeti } \\
\hline \multicolumn{7}{|c|}{ Farklı İşyeri Arkadaşlığı Düzeylerinde Dolaylı Mağduriyetin İntikam Niyetine Etkisi } \\
\hline & B & se & $\mathbf{t}$ & $\mathbf{p}$ & LLCI & ULCI \\
\hline$-1 \mathrm{SD}$ & ,3488 &, 0823 & 4,2385 &, 0000 & , 1869 &, 5107 \\
\hline M & ,2504 &, 0600 & 4,1706 & ,0000 & ,1323 & ,3685 \\
\hline $1 \mathrm{SD}$ &, 1520 & ,0737 & 2,0625 & ,0399 & ,0071 & ,2969 \\
\hline
\end{tabular}

Not: LLCI = \% 95güven aralığının alt sınırı; ULCI = \% 95güven aralığının üst sınırı

Yanlılık hatasından arındırılmış 5000 örneklem bootstrap metodu kullanıldı. Regresyon katsayıları standardize edilmedi. 
$\mathrm{Bu}$ sonuçlardan hareketle Grafik 2'de de görülebileceği gibi düzenleyici değişken olarak tanımlanan işyeri arkadaşlı̆̆ ortalamanın bir standart sapma altı olarak $(-1,00$ SD) düşük, ortalama civarında orta $(, 00)$, ortalamanın bir standart sapma üstü $(+1,00 \mathrm{SD})$ yüksek şeklinde tanımlanan üç koşulda da dolaylı mağduriyet ve intikam niyeti ilişkisini düzenlemede anlamlı bir etkiye sahip olduğu belirlenmiştir. göstermiştir. Ancak bu etkide doğrudan ve dolaylı mağduriyetin intikam niyetini açıklama gücünün zayıf olduğu da ulaşılan bir başka sonuçtur. Ayrıca doğrudan ve dolaylı mağduriyetin, intikam niyeti üzerindeki olumlu yöndeki etkisinde, işyeri arkadaşlığı düzenleyici bir rol oynamaktadır. Zira çalışmada düzenleyici değişken olarak ele alınan işyeri arkadaşlığının ortalaması da yüksektir. Çalışmada ulaşılan önemli bir başka sonuç ise işyeri

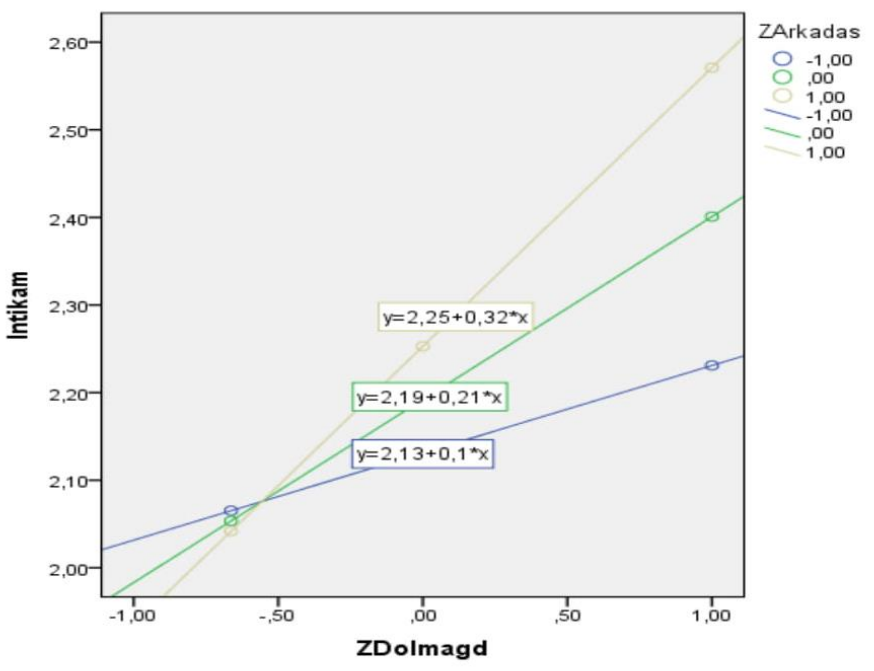

Grafik 2: Farklı İşyeri Arkadaşlığı Düzeylerinde Dolaylı Mağduriyet ve İntikam Niyeti İlișkisi

Elde edilen bu sonuçlara göre işyeri arkadaşlığının, dolaylı mağduriyet ve intikam niyeti arasında düzenleyici değişken etkisine sahip olduğu sonucuna varılmıştır. $\mathrm{Bu}$ sonuçlardan hareketle araştırma için geliştirilen $\mathrm{H}_{4}$ hipotezi kabul edilmektedir.

$\mathrm{Bu}$ sonuçlar, işyerinde doğrudan ve dolaylı mağduriyet yaşayanların normal şartlarda intikam niyetine yöneleceğini ancak işyerinde arkadaşlık ilişkileri iyi veya olumlu ise intikam niyetinin azalacağı veya tersinden işyerinde arkadaşlık ilişkileri olumlu değil ise intikam niyetinin artacağı şeklinde değerlendirilebilir.

\section{TARTIŞMA VE SONUÇ}

Çalışmanın sonuçlarına göre çalışanların doğrudan ve dolaylı mağduriyet algılamalarının düşük olduğu bir başka deyişle mağdur olmadıkları tespit edilmiştir. İntikam niyetinin de düşük olduğu görülmüştür. Çalışmanın mağduriyet ve intikam niyeti arasındaki etkileşime dair sonuçları, örgütlerde çalışanların karşı karşıya kaldıkları doğrudan ve dolaylı mağduriyet algılamalarının, onların intikam niyetlerini pozitif yönde etkilediğini arkadaşlığı, doğrudan ve dolaylı mağduriyetin intikam niyeti üzerindeki pozitif yönlü etkisini zayıflatmakta bir başka deyişle intikam alma eğilimini azaltmakta oluşudur. Bu sonuçlar ilgili alan yazındaki; Gerlsma ve Lugtmeyer, (2018), Aquino ve Thau (2009), Yılmaz (2014) ve Çoklar (2014) tarafindan yapılan çalışmaların bulgularını destekler mahiyettedir.

Öte yandan örgütlerde yaşanan mağduriyetler, her zaman intikam niyetine yönelmeyi gerektirmek durumunda değildir. Sadhu (2014), intikama farklı bir bakış açısı ile yaklaşarak, dini duyguların veya "ilahi adalet" inancının intikamı engelleyici olabileceğini, aksi durumda kişiyi kızgınlık ve hüsrana yöneltmiş her olayın kişide intikam arayışı için sebep olabileceğini ifade etmiştir. Özellikle ülkelerin veya toplumların kültürel ve dini değer yarg1ları onları intikam alma niyetinden uzaklaştırıcı bir rol oynayabilir. Nitekim İslam dininde intikam almak yerine; affetmenin, merhamet göstermenin daha erdemli bir hareket olduğu ve takdir edildiği vurgulanmaktadır. Ayrıca ilahi adalet olgusuna inanç, kişileri rahatlatmakta ve intikam alma niyetinden vazgeçmelerine neden olmaktadır. Tatarlar ve Çangarlı (2018) tarafından yapılan nitel metodolojiye dayalı bir çalışmada da Türk insanının kültürel değerlerinin intikam almak yerine sorunu yüce yaratıcının takdirine bırakma 
eğilimini öne çıkardığı tespit edilmiştir. $\mathrm{Bu}$ çalışmanın bulgularından olan intikam niyetinin düşük çıkması sonucundan hareketle, çalışmanın Kayseri gibi görece daha muhafazakâr bir toplumsal kültür yapısına sahip kitle üzerinde yapılmasının etkili olduğu ve bu sonucun Tatarlar ve Çangarlı (2018) tarafından yapılan çalışmanın bulguları ile paralellik gösterdiğinden söz edilebilir.

Elde edilen sonuçlar, çalışma yaşamına yönelik bazı önerileri de beraberinde getirmektedir. $\mathrm{Bu}$ kapsamda iş ortamında görülen mağduriyetlerin sebebini oluşturan sapkın davranışların engellenmesi, potansiyel intikam alma niyetlerinin de kontrol altına alınmasını sağlayabilir. Örgütsel amaç ve hedefleri ön plana çıkaran ve çalışanların birbirlerini mağdur etmeye değil de yaptıkları işe odaklanmalarını sağlayıcı bir kurumsal kültür geliştirilebilir. İşletmede mağdur veya mağdurların intikam almaya niyetlenerek enerjilerini iç çekişmelerle tüketmelerinin önüne geçmek amacıyla intikam almanın olumsuz yönlerinin de işleneceği eğitimler verilebilir.

$\mathrm{Bu}$ çalışmanın bazı kısıtları da bulunmaktadır. İlk kısıtı araştırmanın örneklemi oluşturmaktadır. Çalışma bir özel sektör işletmesinde yapılmıştır. Bu durum bulguların diğer işletmeler açısından (örneğin kamu işletmeleri) genellenebilirliği bakımından bir kısıt oluşturmaktadır. Araştırmanın kesitsel olması bir başka kısıt olarak yanıtlayıcıların o anki ruh hali ve içinde bulundukları duruma göre değerlendirme yapmalarına ve genel durumu göz ardı etmelerine sebep olmuş olabilir. $\mathrm{Bu}$ sorun boylamsal araştırmalarla giderilebilir.

Bundan sonra yapılacak çalışmalarda örgüt kültürünün, çalışma şekillerinin, yönetici kademesindeki çalışanların tutum ve davranışlarından kaynaklı faktörlerin, çalışanların mağduriyet algılamasının intikam niyeti üzerindeki etkisinde farklılıklara sebep olup olmadığ araştırılabilir. İntikam konusu, affetme konusu ile birlikte ele alınabilir, kişilerin hangi durumda intikam hangi durumda affetme yönlü eğilim ortaya koyacağı daha detaylı bir şekilde incelenebilir. Mağduriyet ve intikam kavramı ilişkisi ele alınırken toplumsal kültürün bir boyutu olan dindarlık düzeyinin bu ilişkide bir düzenleyici rolü olup olmadığı da araştırılarak ilgili alan yazının zenginlik ve derinlik kazanmasına katkıda bulunulabilir.

\section{KAYNAKÇA}

Adams, R. G. \& Blieszner, R. (1994), An integrative conceptual framework for friendship research. Journal of Social and Personal Relationships, 11, 163-184.

Akın, M., Özdevecioğlu, M. \& Ünlü, O. (2012). Örgütlerde intikam niyeti ve affetme eğiliminin çalışanların ruh sağlıkları ile ilişkisi. Amme İdaresi Dergisi, 45(1), 77-97.

Aksu, G., Eser, M. T. \& Güzeller, C. O. (2017). Açımlayıcı ve doğrulayıcı faktör analizi ile yapısal eşitlik modeli uygulamaları. Detay Yayıncılık, Ankara.

Alparslan, A. M., Çiçek, H. \& Soydemir, S. (2015). Birey-örgüt uyumunu güçlendiren öncül: İşyeri arkadaşlı̆̆ı. Akdeniz İ.İ.B.F Dergisi, 32, 175-194.

Aquino, K. (2000). Structural and individual determinants of workplace victimization: The effects of hierarchical status and conflict management style. Journal of Management, 26(2), 171-193.

Aquino, K. \& Bradfield, M. (2000). Perceived victimization in the workplace: The roleof situational factors and victim characteristics. Organization Sicence, 11(5), 525-537.

Aquino, K., Grover, S. L., Bradfield, M. \& Allen, D. G. (1999). The effects of negative affectivity, hierarchical status, and self-determination on workplace victimization. Academy of Management Journal, 42(3), 260-272.

Aquino, K. \& Lamertz, K. (2004). A relational model of workplace victimization: Social roles and patterns of victimization in dyadic relationships. Journal of Applied Psychology, 89(6), 1023-1034.

Aquino, K. \& Thau, S. (2009). Workplace victimization: Aggression from the target's perspective. Annual Review of Psychology, 60(1), 717-741.

Bies, R. J. \& Tripp, T. M. (1996). Beyond distrust: "Getting even" and the need for revenge. In, R. M. Kramer \& T. Tyler (Eds.), Trust in organizations, (pp. 246-260). Newbury Park, CA: Sage.

Bies, R., Aquino, K. \& Tripp, T. (2007), Vigilante model of justice: revenge, reconciliation, forgiveness, and avoidance, Social Justice Research, 20(1), 10-34.

Byrne, D. \& Clore, G. L. (1970). A reinforcement model of evaluative responses. Personality: An International Journal, 1, 103-128.

Cohen, L. E. \& Felson, M. 1979. Social change and crime rate trends: a routine activity approach, American Sociological Review, 44, 588-608 
Çevik, A. (2013). Mağduriyet psikolojisi ve toplumsal yansımaları. 21. Yüzyılda Sosyal Bilimler (2), 65-84.

Çoklar, I. (2014). Kişilik özellikleri ile bă̆ışlama eğilimi arasındaki ilişkinin intikam güdüsü ve adalete duyalılık temelinde incelenmesi (Yayımlanmamış Doktora Tezi). Ankara Üniversitesi, Ankara.

Çokluk, Ö., Şekercioğlu, G. \& Büyüköztürk, Ş. (2012). Sosyal bilimler için çok değişkenli istatistik: SPSS ve Lisrel uygulamalart. Ankara: Pegem Akademi.

Emerson, R. M. (1976). Social exchange theory, Annual Review of Sociology, 2: 335-362.

Festinger, L. (1954). A theory of social comparison processes. Human Relations, 7, 117-140.

Frederick, T. J., McCarthy, B. \& Hagan, J. (2013). Perceived danger and offending: Exploring the links between violent victimization and street crime. Violence and Victims, 28(1), 16-35.

Gemlik, N., Sığrı, Ü. \& Sur, H. (2007). Sosyal karşılaştırma ve öğrenilmiş güçlülük ilişkisinin yönetsel etkileri: hastane yöneticileri ve çalışanları üzerine bir araştırma. Yönetim, 18(57), 55-66.

Gerlsma, C. \& Lugtmeyer V. (2018). Offense type as determinant of revenge and forgiveness after victimization: adolescents' responses to injustice and aggression. Journal of School Violence, 17(1), 16-27.

Gül, H. (2010), Saldırgan Davranışlar ve Örgütsel Mağduriyet Üzerine Kavramsal Bir Araştırma. KMÜ Sosyal ve Ekonomik Araştırmalar Dergisi, 12(18), 9198.

Gürbüz, S. \& Şahin, F. (2014). Sosyal bilimlerde araştırma yöntemleri felsefe- yöntem-analiz Seçkin Yayınevi, Ankara.

Hayes, A. F. (2013). Introduction to Mediation, Moderation, and Conditional Process Analysis. The Guildford Press: New York, NY.

Hindelang, M. S., Gottfredson M. \& Garofalo J. (1978), Victims of Personal Crime. Cambridge, Mass: Ballinger.

İlhan, M. \& Çetin B. (2014), LISREL ve AMOS Programları Kullanılarak Gerçekleştirilen Yapısal Eşitlik Modeli (YEM) Analizlerine İlişkin Sonuçların Karşılaştırılması, Eğitimde ve Psikolojide Ölçme ve Değerlendirme Dergisi, 5(2), 26-42.

Jermier, J. M., Knights, D. \& Nord, W. R. (1994). Resistance and power in organizations. New York: Routledge.

Kaukiainen, A., Salmivalli, C., Björkqvist, K., Österman, K., Lahtinen, A., Kostamo, A. \& Lagerspetz, K. (2001). Overt and covert aggression in work settings in relation to the subjective well-being of employees. Aggressive Behavior, 27, 360-371.

Kram, K. E. \& Isabella, L. A. (1985). Mentoring alternatives: The role of peer relationsips in career development. Academy of Management Journal, 28(1), 110-132.

Lapierre, L. M., Spector, P. E. \& Leck, J. D. (2005). Sexual versus nonsexual workplace aggression and victims' overall job satisfaction: A meta-analysis. Journal of Occupational Health Psychology, 10(2), 155-169.

LeBlanc, M. M. \& Kelloway, E. K. (2002). Predictors and outcomes of workplace violence and aggression. Journal of Applied Psychology, 87(3), 444-453.

Nielsen, I. K. \& Jex, S. M. \& Adams, G. A. (2000), Development and validation of scores on a two dimensional workplace friendship scale, Educational and Psychological Measurement, 60, 628-643.

O'Leary-Kelly, A. M., Griffin, R. W. \& Glew, D.J. (1996). Organization-motivated aggression: A research framework. Academy of Management Review, 21, 225-253.

Özdevecioğlu, M. \& Çelik, C. (2009). Örgüt kültürü tipleri itibariyle bireylerin algıladıkları mağduriyet farklılıklarını belirlemeye yönelik bir araştırma. Atatürk Üniversitesi İktisadi ve İdari Bilimler Dergisi, 23(1), 95-111.

Sadhu, S. (2014). Is Taking a Revenge on Someone a Good Thing or a Bad One? Retrieved from https://www.quora.com/Is-taking-a-revenge-onsomeone-agood- thing-or-a-bad-one

Schermelleh-Engel, K., Moosbrugger, H. \& Müller, H. (2003). Evaluating the fit of structural equation models: Tests of significance and descriptive goodness-of-fit measures. Methods of Psychological Research Online, 8(2), 23-74.

Tabachnick, B. \& Fidell, L. (2012). Using multivariate statics (Pearson, USA).

Tatarlar, C. D. \& Çangarlı Güneri, B. (2018). İntikam mı affetme mi? Örgütsel yaşamda çok bilinmeyenli bir denklem. Ege Academic Review, 18(4), 591-603.

Taylor, S. E., Wood, J. V. \& Lichtman, R. R. (1983). It could be worse:Selective Evaluation as a response to victimization. Journal of Social Issues, 39(2), 19-40.

Ülbeği, İ. D., Özgen, H. \& Özgen, H. (2014). Algılanan mağduriyet ölçeğinin Türkçe uyarlaması: Güvenirlik ve geçerlik analizi. Ç.Ü. Sosyal Bilimler Enstitüsü Dergisi, 23(2), 101-112.

Wade, S. H. (1989). The Development of a Scale to Measure Forgiveness (Unpublished Doctoral 
Dissertation). Fuller Theological Seminary: California.

Yılmaz, Ö. D. (2014). Algılanan mağduriyetin affetme eğilimi ve intikam niyeti üzerindeki etkisi: Konaklama işletmeleri çalışanlarına yönelik bir araştırma. Akü Iibf Dergisi, 16(1), 87-105. 